\title{
A SARS-Coronovirus 3CL Protease Inhibitor Isolated from the Marine Sponge Axinella cf. corrugata: Structure Elucidation and Synthesis
}

\author{
Simone P. de Lira, ${ }^{a}$ Mirna H. R. Seleghim, ${ }^{a}$ David E. Williams, ${ }^{b}$ Frederic Marion, ${ }^{b}$ Pamela Hamill, ${ }^{c}$ \\ François Jean, ${ }^{c}$ Raymond J. Andersen, ${ }^{b}$ Eduardo Hajdu ${ }^{d}$ and Roberto G. S. Berlinck ${ }^{*, a}$ \\ ${ }^{a}$ Instituto de Química de São Carlos, Universidade de São Paulo, CP 780, \\ 13560-970 São Carlos-SP, Brazil \\ ${ }^{b}$ Department of Chemistry and Department of Earth and Ocean Sciences, University of British Columbia, \\ Vancouver, British Columbia, V6T 1Z1 Canada \\ ${ }^{c}$ Department of Microbiology and Immunology, Life Sciences Centre, University of British Columbia, \\ Vancouver, BC V6T 1Z3, Canada \\ ${ }^{d}$ Museu Nacional, Universidade Federal do Rio de Janeiro, Quinta da Boa Vista, s/n, \\ 20940-040 Rio de Janeiro-RJ, Brazil
}

\begin{abstract}
Dois derivados cumarínicos, o ester metílico do ácido 4-esculetinocarboxílico (1) e o éster etílico do ácido 4-esculetinocarboxílico (2), foram isolados da esponja marinha Axinella cf. corrugata. A determinação estrutural dos compostos isolados foi realizada pela análise de seus dados espectroscópicos e pela síntese do composto 2. Estes são os primeiros derivados cumarínicos isolados de uma esponja marinha. O éster etílico 2 apresentou atividade in vitro contra a SARS 3Cl-protease e de inibição de células Vero infectadas com o SARS coronavírus, em concentrações que não provocaram citotoxicidade.
\end{abstract}

Two coumarin derivatives, esculetin-4-carboxylic acid methyl ester (1) and esculetin-4carboxylic acid ethyl ester (2), have been isolated from the marine sponge Axinella cf. corrugata. Structure determination included analysis of spectroscopic data and total synthesis of compound 2. These are the first coumarin derivatives isolated from a marine sponge. The ethyl ester $\mathbf{2}$ was found to be an in vitro inhibitor of SARS 3CL-protease and an effective inhibitor of SARS-CoV replication in Vero cells at non-cytotoxic concentrations.

Keywords: esculetin, marine sponge, Axinella cf. corrugata, SARS, anti-viral

\section{Introduction}

In 2002 and 2003, several cases of a life-threatening respiratory disease that was ultimately named "severe acute respiratory syndrome" (SARS) were reported from Guangdong Province in mainland China, Hong Kong, Canada, and Vietnam. ${ }^{1}$ The etiological agent responsible for SARS was quickly found to be a novel coronavirus (SARS-CoV). Among the viral gene products are several large polyproteins that must be proteolytically processed to generate the individual proteins required for viral replication to occur. Two viral proteases, PL2 ${ }^{\text {pro }}$ and $3 \mathrm{CL}^{\text {pro }}$, are involved in degrading the large polyproteins. ${ }^{2}$

*e-mail: rgsberlinck@iqsc.usp.br
The viral protease $3 \mathrm{CL}^{\text {pro }}$ is considered the most important of the two because it is responsible for the release of the key replicative proteins of the vírus, including the viral RNA polymerase and helicase proteins. The central role of $3 \mathrm{CL}^{\text {pro }}$ in SARS-CoV replication has made it a high profile target for developing antiviral drugs to treat SARS. ${ }^{2}$ Recently, a novel fluorescence resonance energy transfer (FRET)based assay to screen for $3 \mathrm{CL}^{\text {pro }}$ inhibitors has been developed in one of our laboratories. ${ }^{3}$ As part of a screening of crude marine sponge extracts and pure compounds isolated from the marine sponges using this assay, we have found that the new natural product esculetin-4-carboxylic acid ethyl ester (2) isolated from Axinella cf. corrugata collected in Brazil is a an effective inhibitor of $3 \mathrm{CL}^{\text {pro }}$ in vitro. 
In our current search for new biologically active marine natural products, ${ }^{4,5}$ we decided to investigate the $\mathrm{MeOH}$ crude extract of the sponge Axinella cf. corrugata, which displayed cytotoxic activity against breast MCF7 and colon B16 cancer cell lines. Although the cytotoxic activity was lost during the crude extract fractionation, photodiode array detection-HPLC analysis of the chromatographic fractions obtained indicated the presence of metabolites with UV absorptions at $\lambda_{\text {max }} 207$, 239, 271 and $375 \mathrm{~nm}$, an absorption profile not found in MARINLIT database. Further separation and purification yielded the new metabolites esculetin-4-carboxylic acid methyl ester (1) and esculetin-4-carboxylic acid ethyl ester (2), probably as artifacts of isolation of the herein reported new coumarin derivative esculetin-4-carboxylic acid with $\mathrm{MeOH}$ and $\mathrm{EtOH}$, used in the extraction procedure. The pure compounds $\mathbf{1}$ and $\mathbf{2}$ were subsequently screened in a panel of biological assays resulting in the discovery that compound $\mathbf{2}$ was an inhibitor of $3 \mathrm{CL}^{\text {pro }}{ }^{3}$ Herein we present details of the isolation, structure determination of $\mathbf{1}$ and $\mathbf{2}$, along with the total synthesis of compound $\mathbf{2}$ in order to confirm the structure proposal.

\section{Results and Discussion}

Esculetin-4-carboxylic acid methyl ester (1) displayed a molecular ion peak corresponding to its dimerized sodium adduct at $\mathrm{m} / \mathrm{z}, 495$ (TOF/ESI-MS). A high resolution mass measurement at $\mathrm{m} / \mathrm{z} 495.0544$ (Calc. 495.0539) indicated the formula $\mathrm{C}_{22} \mathrm{H}_{16} \mathrm{O}_{12} \mathrm{Na}$. Considering the ${ }^{13} \mathrm{C}$ NMR spectrum of $\mathbf{1}$ which displayed only eleven carbons, the molecular weight measurement indicated that either the compound presented internal symmetry or it was detected as a dimerized molecular ion. The last assumption has proven to be true after the total synthesis of compound 2 (see below) and recording the mass spectrum of the synthetic product, which displayed the same dimerized molecular ion. Seven carbons of esculetin-4-carboxylic acid methyl ester (1) were shown to be quaternary $\mathrm{sp}^{2}$ by DEPT ${ }^{13} \mathrm{C}$ NMR $(\delta 164.4,160.0,150.9,148.8,143.0$, $142.5,107.0)$. Three of the remaining carbons were methine $\operatorname{sp}^{2}(\delta 113.5,110.3,102.9)$ and one methyl group $\left(\delta\right.$ 53.0). The ${ }^{1} \mathrm{H}$ NMR spectrum of 1 displayed six singlets. The HSQC experiment indicated that two of these singlets could be assigned to phenol hydrogens $(\delta 10.44$ and 9.60), three to vinylic and/or aromatic hydrogens at $\delta 7.46,6.80$ and 6.60 attached to the corresponding $\mathrm{sp}^{2}$ carbons at $\delta 110.3,102.9$ and 113.5, respectively, and one methoxyl group at $\delta 3.91$ ( $\delta$ 53.0).
The ${ }^{1} \mathrm{H}-{ }^{1} \mathrm{H}$ COSY spectrum of $\mathbf{1}$ indicated a very weak long-range ${ }^{1} \mathrm{H}-{ }^{1} \mathrm{H}$ coupling between the singlets at $\delta$ 7.46 and 6.80 , suggesting a 1,4-aromatic relationship between these hydrogens. Since the HMBC spectrum displayed correlations of both hydrogens at $\delta 7.46$ and 6.80 with carbons at $\delta 150.9$ and 148.8 , which were also coupled with both phenolic hydrogens at $\delta 10.44$ and 9.60, the ${ }^{1} \mathrm{H}-{ }^{1} \mathrm{H}$ and ${ }^{1} \mathrm{H}-{ }^{13} \mathrm{C}$ correlation data enabled us to define the aromatic portion of esculetin-4carboxylic acid methyl ester (1) as a 1,2,4,5tetrasubstituted benzene ring, with two hydroxyl groups at vicinal positions. The remaining vinylic hydrogen at $\delta 6.60$ displayed long range correlations with two carbonyl groups at $\delta 164.4$ and 160.0. Since the methyl group at $\delta 3.91$ (s) also presented a long range correlation with carbonyl at $\delta 164.4$, it was assigned to a methyl ester group. Considering the number of eight unsaturations established by half of the molecular formula as indicated above and the number of $\mathrm{sp}^{2}$ carbons observed in the ${ }^{13} \mathrm{C}$ NMR spectrum, the remaining carbonyl group at $\delta 160.0$ was assigned to a lactone moiety of a coumarin-like skeleton. The positions of the hydroxyl groups were assigned to carbons 6 and 7, as in esculetin (3). The methyl ester group might be placed at either $\mathrm{C}-3$ or $\mathrm{C}-4$, giving rise to two possible isomeric structures, $\mathbf{1}$ or $\mathbf{4}$, which could not be distinguished by the long range correlations observed for the hydrogen at $\delta 6.60$ with both carbonyl groups, since in both cases these are correlations through two or three bonds. However, the HMBC spectrum clearly indicated that hydrogens at $\delta 6.60$ and 6.80 presented a long-range correlation with the carbon at $\delta$ 107.0. Therefore, structure 1 was favoured, in which the carbon with chemical shift at $\delta 107.0$ was assigned to $\mathrm{C}-4$, which was ${ }^{3} \mathrm{~J}$ coupled with the aromatic hydrogen at $\delta 6.80$ and ${ }^{2} J$ coupled to the vinylic hydrogen at $\delta 6.60$. Additionally, a hydrogen at C-4 position would present a higher chemical shift, since it would be at a $\beta$-position of an $\alpha, \beta$-conjugated double bond with two carbonyl groups. The two remaining quaternary $\mathrm{sp}^{2}$ carbons at $\delta 142.5$ and 143.0 were assigned to $\mathrm{C}-9$ and $\mathrm{C}-10$, both assignments being interchangeable.

Esculetin-4-carboxylic acid ethyl ester (2) displayed a molecular ion peak for its dimerized sodium adduct at $\mathrm{m} / \mathrm{z}$ 523. Since the high resolution mass measurement at $\mathrm{m} / \mathrm{z} 523.0843$ (Calc. 523.0852) indicated the formula $\mathrm{C}_{24} \mathrm{H}_{20} \mathrm{O}_{12} \mathrm{Na}$, and its ${ }^{1} \mathrm{H},{ }^{13} \mathrm{C}$, and HMBC NMR spectra indicated the presence of an ethoxy group $\left({ }^{1} \mathrm{H} 3.37\right.$, q, 7 $\left.\mathrm{Hz}, 2 \mathrm{H} ; \delta{ }^{13} \mathrm{C} 62.0 ; \delta{ }^{1} \mathrm{H} 1.35, \mathrm{t}, 7 \mathrm{~Hz}, 3 \mathrm{H} ; \delta{ }^{13} \mathrm{C} 13.7\right)$ coupled to the $\mathrm{C}-11$ ester carbonyl as the only difference 
to $\mathbf{1}$, we have assigned the structure of the corresponding ethyl ester to $\mathbf{2}$.

In order to confirm our structure proposal, we have performed the total synthesis of compound $\mathbf{2}$ in three steps from 3-hydroxy-4-methoxybenzaldehyde (5) following the procedure described for the synthesis of scopoletin (Scheme 1). ${ }^{6}$ The intermediate scopoletin-4-carboxylic acid ethyl ester (7) was deprotected with using boron tribromide providing esculetin-4-carboxylic acid ethyl ester (2) in $27 \%$ overall yield.

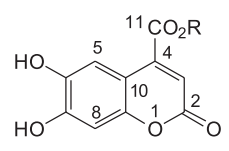

$1 \mathrm{R}=\mathrm{Me}$ $1 \mathrm{R}=\mathrm{Me}$
$2 \mathrm{R}=\mathrm{Et}$

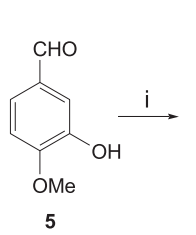

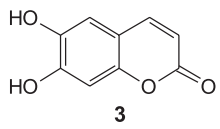
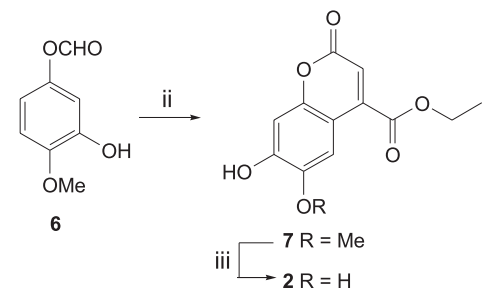

Scheme 1. Synthetic route for 2. Reaction conditions: i, $m$-CPBA, $\mathrm{CH}_{2} \mathrm{Cl}_{2}$, $70 \%$; ii, $\mathrm{SDO}, \mathrm{H}_{3} \mathrm{PO}_{4}, 46 \%$; iii, $\mathrm{BBr}_{3}, \mathrm{CH}_{2} \mathrm{Cl}_{2}, 84 \%$.

The isolation of esculetin-4-carboxylic acid as its corresponding methyl and ethyl esters is probably due to the extraction of Axinella cf. corrugata with $\mathrm{MeOH}$ and EtOH. Esculetin-4-carboxylic acid is not known as a natural product, but it has been synthesized during a survey for inhibitors of DOPA decarboxylase. ${ }^{7}$ Considering the small amount isolated of both esculetin-4-carboxylic acid methyl ester and ethyl ester, it is reasonable to suggest a microbial origin for such compounds, although the occurrence of coumarin derivatives in fungi and bacteria has not been frequently observed. ${ }^{8}$ Metabolites bearing a coumarin moiety have been isolated from the marine fungus Trichoderma virens ${ }^{9}$ and from the marine ascomycete Leptosphaeria oraemaris. ${ }^{10}$ The isolation of plant-related metabolites from sponges is rare. Only two examples are found in the literature: resorcinol derivatives from Haliclona sp. ${ }^{11}$ and triptophol, an auxin derivative, from Ircinia spinulosa. ${ }^{12}$

Esculetin-4-carboxylic acid ethyl ester (2) was found to inhibit recombinant $3 \mathrm{CL}^{\text {pro }}$ in vitro with an $\mathrm{ID}_{50}$ value of $46 \mu \mathrm{mol} \mathrm{L}{ }^{-1}{ }^{3}$ It has also been shown that 2 is an effective inhibitor of SARS-CoV replication in Vero cells $\left(\mathrm{EC}_{50}=112 \mu \mathrm{mol} \mathrm{L}{ }^{-1}\right)$ and that it mediates these effects at non-cytotoxic concentrations (2: Vero cell cytotoxicity $\left.\mathrm{IC}_{50}>800 \mu \mathrm{mol} \mathrm{L}^{-1}\right){ }^{4 \mathrm{~b}}$ Further studies on the antiviral properties of $\mathbf{2}$ are ongoing and the results will be reported elsewhere.

\section{Supplementary Information}

Experimental details and spectra are given as supplementary information at http://jbcs.sbq.org.br, as PDF file.

\section{Acknowledgments}

The authors thank Professor Maria da Glória B. S. Moreira, past principal of the Centro de Biologia Marinha, for providing facilities for the sponge collection and also Prof. Gil V. J. Silva and Virginia H. B. Glass (Depertamento de Química, Faculdade de Filosofia, Ciências e Letras de Ribeirão Preto, Universidade de São Paulo) in obtaining the NMR spectra of the natural products. Financial support was provided by FAPESP (01/03095-5 to RGSB) and the Natural Sciences and Engineering Research Council of Canada (RJA). SPL thanks FAPESP for the award of a scholarship and FM was supported by a Fellowship from Pierre Fabre.

\section{References}

1. Drosten, C.; Gunther, S.; Preiser, W.; van der Werf, S.; Brodt, H. R.; Becker, S.; Rabenau, H.; Panning, M.; Kolesnikova, L.; Fouchier, R. A. M.; Berger, A.; Burguiere, A. M.; Cinatl, J.; Eickmann, M.; Escriou, N.; Grywna, K.; Kramme, S.; Manuguerra, J. C.; Muller, S.; Rickerts, V.; Sturmer, M.; Vieth, S.; Klenk, H. D.; Osterhaus, A. D. M. E.; Schmitz, H.; Doerr, H. W.; N. Engl. J. Med. 2003, 348, 1967.

2. Anand, K.; Ziebuhr, J.; Wadhwani, P.; Mesters, J. R.; Hilgenfeld, R.; Science 2003, 300, 1763.

3. Hamill, P.; Hudson, D.; Kao, R. Y.; Chow, P.; Raj, M.; Xu, H.; Richer, M. J.; Jean, F.; Biol. Chem. 2006, 387, 1063.

4. Oliveira, J. H. H. L.; Seleghim, M. H. R.; Timm, C.; Grube, A.; Köck, M.; Nascimento, G. G. F.; Martins, A. C. T.; Silva, E. G. O.; Souza, A. O.; Galetti, F. C. S.; Minarini, P. R. R.; Silva, C. L. L.; Hajdu, E.; Berlinck, R. G. S.; Mar. Drugs 2006, 4, 1; Oliveira, M. F.; Oliveira, J. H. H. L.; Galetti, F. C. S.; Souza, A. O.; Silva, C. L.; Hajdu, E.; Peixinho, S.; Berlinck, R. G. S.; Planta Med. 2006, 72, 437.

5. Williams, D. E.; Austin, P.; Diaz-Marrero, A. R.; Van Soest, R.; Matainaho, T.; Roskelley, C. D.; Roberge, M.; Andersen, R. J.; Org. Lett. 2005, 7, 4173; Williams, D. E.; Patrick, B. O.; Behrisch, H. W.; Van Soest, R.; Roberge, M.; Andersen, R. J.; J. Nat. Prod. 2005, 68, 327 . 
6. Croby, D. G.; J. Org. Chem. 1961, 26, 1215.

7. Hartman, W. J.; Akawie, R. I.; Clark, W. G.; J. Biol. Chem. 1955, 216, 507.

8. Literature searches in SciFinder database provide only a limited number of records related to the occurrence of coumarin derivatives in bacteria and fungi. See Chen, H.; Walsh, C. T.; Chem. Biol. 2001, 8, 301; Pedras, M. S. C.; Chumala, P. B.; Phytochemistry 2005, 66, 81.

9. Garo, E., Starks, C. M.; Jensen, P. R.; Fenical, W.; Lobkovsky, E.; Clardy, J.; J. Nat. Prod. 2003, 66, 423.
10. Guerriero, A.; D’Ambrosio, M.; Cuomo, V.; Pietra, F.; Helv. Chim. Acta 1991, 74, 1445.

11. Barrow, R. A.; Capon, R. J.; Aust. J. Chem. 1991, 44, 1393.

12. Erdogan, I.; Sener, B.; Higa, T.; Biochem. Syst. Ecol. 2000, 28 , 793.

Received: August 21, 2006

Web Release Date: March 16, 2007

FAPESP helped in meeting the publication costs of this article. 